\title{
Constantino Carvallo
}
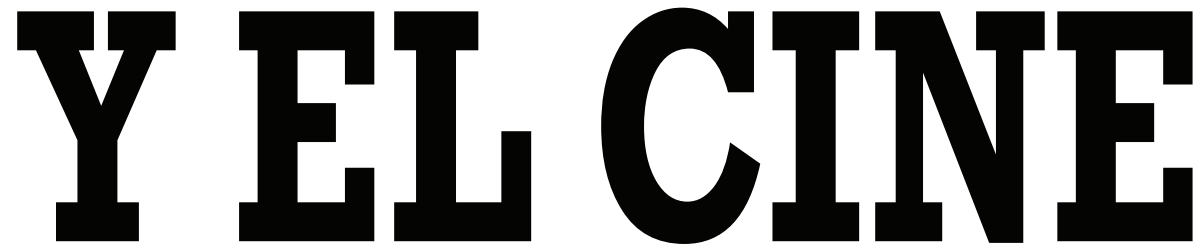

Isaac León Frías

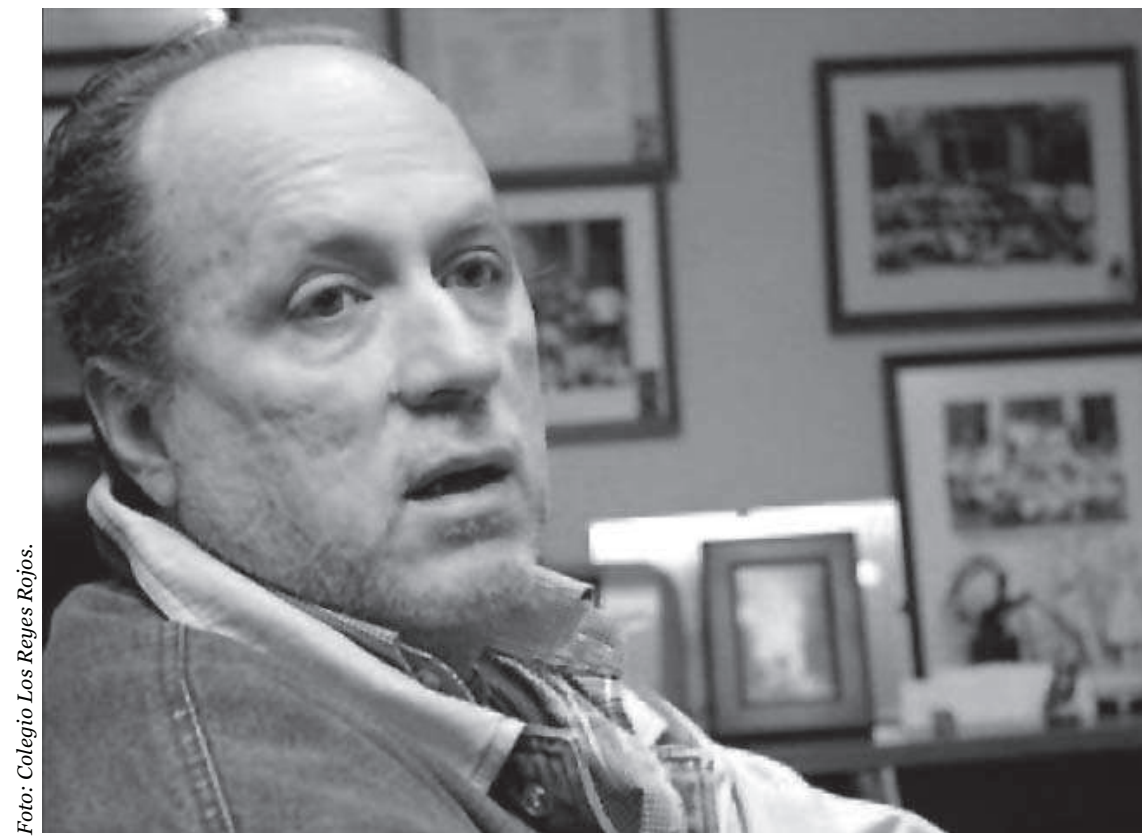

ntre 1973 y 1974 varios jóvenes se incorporaron a la revista Hablemos de Cine, fundada en 1965. Uno de ellos fue Ricardo Bedoya. Otros, José Carlos Huayhuaca, Reynaldo Ledgard y un poco más tarde Constantino Carvallo. Con ellos la vida de la revista, que se hizo siempre en equipo y con reuniones semanales (o más) permanentes, se reactivó y experimentó varios años en los que la intensidad vivida tras bambalinas no se reflejó fielmente en una periodicidad accidentada. Constantino fue uno de los más decididos polemistas en las reuniones que se prolongaban hasta horas de la madrugada. Los estrenos de los jueves podían ser el pretexto de diálogos vehementes, pero también el cine peruano y la obra de autores de diversa procedencia, sin que quedaran fuera temas conexos o, incluso, ajenos al cine. Si esos diálogos se hubieran grabado, tendríamos ahora un valioso material de análisis, a veces, muy puntilloso, que tenía en Constantino a uno de sus principales exponentes. Carvallo hizo críticas, participó en entrevistas y mesas redondas, inclinándose con frecuencia hacia el tono beligerante que la revista había tenido en sus primeros tiempos y que, en parte, se actualizó entre 1974 y 1980. Pero no se limitó a Hablemos de Cine. Con Reynaldo Ledgard alternó en el espacio crítico del semanario Oiga a fines de los años setenta, y más tarde tuvo a su cargo una columna en el diario $\mathrm{El} \mathrm{Sol,} \mathrm{de} \mathrm{muy} \mathrm{breve} \mathrm{existencia,} \mathrm{en} \mathrm{la}$ que escribió sobre directores y temas de cine. Su visión de las películas, sin desligarse de la materia expresiva propia del lenguaje audiovisual, supo abrirse a otros territorios desde una perspectiva que a veces podía parecer muy iconoclasta y provocadora, pero que no ocul- taba ese humanismo solidario del que hizo una constante en su vida.

En 1980, y ya comprometido con el proyecto educativo del colegio "Los Reyes Rojos", deja la crítica sin perder el interés por el cine, del cual pueden dar testimonio sus colegas y alumnos del colegio. En más de una ocasión coincidí en salas en las que Constantino estaba con un grupo relativamente amplio de estudiantes de "Los Reyes Rojos". En el colegio que dirigió con tanto empeño adaptó una sala especialmente dedicada a la proyección de películas, cosa inusual en los colegios limeños que suelen tener salas multiusos. En una entrevista con el programa televisivo El placer de los ojos declaró sagazmente que no estaba de acuerdo con los cursos de enseñanza fílmica y audiovisual en los colegios, porque eso terminaría en el simple paporreteo de nombres y títulos, sin que se promoviera una verdadera educación para la comprensión de las imágenes del cine y de la televisión. Su última intervención conocida en la materia fílmica fue en la aguda presentación que hizo del libro de Huayhuaca, Una grieta a lo sublime: Viaje a Italia de Roberto Rossellini, el 2006, donde demostró que no se había perdido en absoluto esa capacidad de comprensión del cine, la que se asoma también, aunque muy fugazmente, en su notable libro Diario educar.

Afortunadamente, el rescate de los artículos de Constantino en Hablemos de Cine, Oiga y El Sol parece garantizado, pues Jorge Eslava se encuentra reuniendo el íntegro de los textos que escribió en diversos espacios. Con ellos quedará registrado que también con respecto al cine Constantino puso la misma cuota de pasión y compromiso que en las otras actividades que impulsó tan provechosamente. Adelantamos ese registro con dos de sus mejores textos. 